\title{
ТРИВАЛІСТЬ ЛАКТАЦІЙНОГО ПЕРІОДУ ТА ФІЗІОЛОГІЧНА АКТИВНІСТЬ КОРІВ ГОЛШТИНСЬКОЇ ПОРОДИ
}

\author{
Гуцуляк Ганна Сергївна \\ аспірант \\ Дніпровський державний аграрно-економічний університет \\ ORCID: 0000-0002-4808-5934 \\ Email: gutsulyk.a@gmail.com
}

Характеризуючи продуктивні якості голштинських корів необхідно відмітити явне зростання надою корів від першої до четвертої лактації, а вже на п'ятій лактації спостерігається незначне зниження удою. Так, для корів третьої лактації були вже не характерні удої до 9000 кә молока. У цей же час у тварин четвертої та п'ятої лактацій також не спостерігалися удої до 9000 ка, але й більще 10000 кг за 305 діб лактації те ж не було. У проведених дослідженнях тривалість лактаційного періоду у різновікових корів значно відхилялась від нормативного показника, який становить 305 діб, тобто 10 місяців. Таким чином, навіть за стимуляції синхронізації овуляції на яєчниках корів тривалість лактації перебільшує нормативні показники. Особливо тривалий лактаційний період у неадаптованих первісток, який перевищує норму на 42,9%. Проте з віком корів лактаційний період хоча і перевищує норму, та все ж помітне незначне його скорочення. Встановлено, що зростання надою корів відбувається від першої до четвертої лактації, а вже на п'ятій лактації спостерігається незначне його зниження, що вказує на деяке фізіологічне виснаження організму. Також про це свідчать показники відношення величини удою до їх живої маси. Так, у голштинських тварин четвертої та п'ятої лактацій відзначається найвищі показники як удою за 305 діб, так і фізіологічної активності організму. За цей період на кілограм живої маси корів приходилося відповідно 15,0 та 16,0 ке секретованого молока, тоді як у тварин першої та другої лактацій цей показник був меншим відповідно на 14,3 і 11,8 \%. Близькі та найменші значення показників молочного жиру та білка мали тварини I і III (контрольної) груп відповідно у першу та третю лактації відповідно 0,5 кг молочного жиру та 0,4 к己 молочного білка на одиницю живої маси. Ці значення поступалися показникам коровам II, IV i V груп відповідно у другу, четверту та п'яту, які, в свою чергу, секретували 0,6 кг молочного жиру та 0,5 кг молочного білка на кілограм живої маси. Реалізація генетичного потенціалу голштинськими коровами не є стабільно запрограмованою, оскільки залежить від індивідуальної реакції на умови експлуатації. На фрізіологічне виснаження організму за інтенсивної технології експлуатації вказує те, що рівень молочної продуктивності у корів від першого до четвертого отелення зростає, після чого дещо знижується.

Ключові слова: удій, корова, лактація, молоко, фрізіологічна активність організму

DOI: https://doi.org/10.32845/bsnau.lvst.2019.1-2.8

На збільшення об'ємів виробництва молока впливає, в першу чергу, якість тварин, яких використовують та їх генетичний потенціал. Також важливим фактором $€$ порода, яка безпосередньо визначає молочну продуктивність корів, фізико-хімічний склад і якість як самого молока, так і продуктів його переробки [1,2]. Серед всіх нині відомих порід молочного напряму найбільшу увагу звернула на себе голштинська порода, яка має чи не найбільший міжконтинентальний ареал та велику кількість світових рекордів за молочною продуктивністю [3,4]

Тому для збільшення молочної продуктивності широко проводиться голштинізація вітчизняної худоби. Вибір цієї породи визначився високою адаптаційною здатністю тварин до інтенсивних технологій виробництва молока, високою інтенсивністю росту молодняку та високим генетичним потенціалом [5].

Лактація - це утворення, нагромадження й виведення молочною залозою молозива, а потім молока в період від отелення до запуску. Його кількість значно залежить від умов годівлі, утримання й догляду за худобою, від індивідуальних особливостей тварин і від їхньої спадковості [6].

Невипадково в перші місяці лактації спостерігається, як правило, деяке зменшення живої маси і вгодованості, зумовлене здатністю високопродуктивних корів використовувати запаси поживних речовин тіла для підтримання максимальних надоїв. Тому дійній корові на початку лактації необхідно давати таку кількість кормів, які вона здатна з'їсти для проявлення своїх генетичних задатків продуктивності. Окрім цього суттєві корективи в реалізації продуктивного потенціалу може вносити технологія експлуатації тварин. Наприклад, порушенням правил доїння корів можна спочатку зменшити удій і, навіть, припинити взагалі лактацію [7].

Чим інтенсивніший обмін речовин в організмі, тим вища молочна продуктивність [8]. Окрім того американський дослідники вказують на цінність молока корів у тому, скільки міститься в ньому енергії.

Тривалість лактаційного періоду безпосередньо залежить від функції відтворення тварин. Тому відтворна здатність молочних корів $€$ важливою складовою комплексної оцінки худоби. Також в умовах інтенсифікації скотарства ріст продуктивності і регулярне відтворення тварин визначають рентабельність господарств.. Одночасне поєднання високої молочної продуктивності та плодючості може вказувати на добру адаптацію тварин до певних умов, що вважається основним фрактором при удосконаленні породи , що розводиться [9].

Постановка завдання: встановити взаємозв'язок рівня фрізіологічної активності та тривалості лактаційного періоду у корів різного віку.

Матеріали та методи досліджень. На промисловому комплексі з виробництва молока, де експлуатуються корови голштинської породи був проведений ретроспективний аналіз 7706 лактацій. В тому числі I група первісток 3772 лактації, II група корів другої лактації - 1928 лактацій,

Вісник Сумського національного аграрного університету 
III (контрольна) група корів третьої лактації - 1318 лактацій, IV група корів четвертої лактації - 449 та V група корів п'ятої лактації - 239 лактацій.

Перші три місяці після отелення корів видоювали три рази, а в подальшому, аж до запуску - два рази на доїльній установці типу «Паралель».

Після отелення всіх корів відповідно до схеми стимуляції та синхронізації еструсу обробляли гормональними препаратами та осіменяли.

Запуск тварин у сухостій проводили відповідно до технології за два місця до отелення.

Відпочинок тварин організовувався у боксах, де у якості підстилки розміщували сухий пісок. Влітку, за підвищеної температури зони утримання розпилювали воду вентиляторами.

Годівля тварин проводилася повнораціонними кормосумішами консервованих кормів з кормового столу безвигульних корівників.

Результати досліджень. Характеризуючи продуктивні якості голштинських корів (табл. 1) необхідно відмітити явне зростання надою корів від першої до четвертої лактації, а вже на п'ятій лактації спостерігається незначне зниження удою. Так, для корів третьої лактації були вже не характерні удої до 9000 кг молока. У цей же час у тварин четвертої та п'ятої лактацій також не спостерігалися удої до 9000 кг, але й більше 10000 кг за 305 діб лактації те ж не було.

У проведених дослідженнях тривалість лактаційного періоду у різновікових корів значно відхилялась від нормативного показника, який становить 305 діб, тобто 10 місяців. Слід відмітити, що це науково обґрунтований період, що забезпечує найвищу функціональну активність лактуючого організму корів. Так, у первісток (I група) лактація була триваліша нормативної на 42,9 \% або майже на 131 доби і становила у середньом 435,8 доби.

У корів другого і четвертого отелення відповідно II і IV групи лактація теж була більше норми і становила у середньому відповідно 444,2 і 451,9 доби, що перевищувало показник первісток (I група) відповідно на 2 і 3,6 \%.

Подовжена лактація спостерігалась і у тварин із третім та п'ятим отеленням відповідно III (контрольна) і V групи, у яких вона складала у середньому відповідно 405,4 і 409,8 доби. Ці значення перевищували норму всього відповідно на 32,9 і 34,4 \%, та поступалися показнику первісток (І група) відповідно на 6,9 і 5,9 \%.

Характеристика продуктивних якостей голштинських корів за інтенсивної технології експлуатації

\begin{tabular}{|c|c|c|c|c|c|c|}
\hline \multirow{3}{*}{$\begin{array}{l}\text { Група тварин за } \\
\text { віком у лактаціях }\end{array}$} & \multirow{3}{*}{ Жива маса, кг } & \multirow{3}{*}{ Лактація, днів } & \multicolumn{4}{|c|}{ Рівень молочної продуктивності } \\
\hline & & & \multicolumn{2}{|c|}{ повна лактація } & \multicolumn{2}{|c|}{305 діб лактації } \\
\hline & & & удій, кг & $\begin{array}{c}\text { те ж у } 4 \text { \%-овому } \\
\text { молоці }\end{array}$ & удій, кг & $\begin{array}{c}\text { те ж у } 4 \% \text { \%-овому } \\
\text { молоці }\end{array}$ \\
\hline$I, n=3772$ & $594,4 \pm 0,40$ & $435,8 \pm 2,50$ & $10712,1 \pm 52,40$ & $10444,1 \pm 51,10$ & $8351,6 \pm 16,90$ & $8142,7 \pm 16,60$ \\
\hline II, $n=1928$ & $640,1 \pm 0,78$ & $444,2 \pm 2,89$ & $11500,3 \pm 67,40$ & $11206,0 \pm 65,30$ & $9207,2 \pm 31,80$ & $8975,5 \pm 31,40$ \\
\hline $\begin{array}{c}\text { III (контрольна), } \\
\text { n=1318 }\end{array}$ & $673,0 \pm 1,0$ & $405,4 \pm 3,70$ & $10949,9 \pm 82,40$ & $10727,3 \pm 8,60$ & $9282,5 \pm 39,60$ & $9101,1 \pm 37,40$ \\
\hline IV, $n=449$ & $630,2 \pm 2,40$ & $451,9 \pm 6,40$ & $11884,4 \pm 144,20$ & $11653,0 \pm 139,70$ & $9575,2 \pm 66,90$ & $9391,5 \pm 64,60$ \\
\hline$V, n=239$ & $584,0 \pm 1,50$ & $409,8 \pm 7,70$ & $11157,6 \pm 192,10$ & $10981,8 \pm 187,70$ & $9315,8 \pm 91,90$ & $9171,8 \pm 89,50$ \\
\hline
\end{tabular}

Таким чином, навіть за стимуляції синхронізації овуляції на яєчниках корів тривалість лактації перебільшує нормативні показники. Особливо тривалий лактаційний період у неадаптованих первісток (I група), який перевищує норму на 42,9 \%. Проте, з віком корів лактаційний період хоча і перевищує норму, та все ж помітне незначне його скорочення.

У проведених дослідженнях чітко видно тенденцію, що із віком корів та зменшенням тривалості лактаційного періоду, зростає рівень удою. Так, починаючи з першої і до третьої лактації показник удою за 305 діб лактації тварин збільшився на 11,7\%, при цьому тривалість лактації за цей період скоротилася на 6,9\%. У корів четвертої лактації (IV група) молочна продуктивність за 305 діб становила в середньому 9391,5 кг. Цей рівень продуктивності практично був таким же, як показник корів третьої лактації (III контрольна група). Удій тварин п'ятої лактації (V група) був вже нижчим ніж у корів попередніх груп і становив 9171,8 кг.

Отже, рівень молочної продуктивності у голштинських корів за інтенсивної технології експлуатації при зменшенні тривалості лактаційного періоду від першого до третього отелення зростає, після чого дещо знижується, що вказує на деяке фізіологічне виснаження організму.

Про фізіологічну напруженість лактуючого організму корів свідчать показники відношення величини удою до їх живої маси (табл. 2), тобто коефіцієнт молочності. У голштинських тварин четвертої та п'ятої лактацій (IV i V групи) відзначається найвищі показники як удою за 305 діб, так і фізіологічної активності організму. За цей період на кілограм живої маси корів приходилося відповідно 15,0 та 16,0 кг секретованого молока, тоді як у тварин першої та другої лактацій (I і || групи) цей показник був меншим відповідно на 14,3 і 11,8\%.

Про рівний потенціал продуктивності свідчать дані найвищого добового надою корів. Так, у тварин другої і третьої лактації (II і III (контрольна) групи) цей показник знаходився на рівні відповідно 29,4 та 29,8 кг молока, а у тварин четвертої і п'ятої лактацій (IV i V групи) відповідно 30,8 і 30,1 кг. Тобто, із збільшенням віку голштинів підвищується реалізація їх генетичного потенціалу.

Так, у період четвертої і пятої лактації (IV i V групи) фрізіологічна активність організму цих повновікових корів перевищувала первісток (I група) відповідно на 13,3 і 11,3\%. 
Таблиця 2

Фізіологічна активність організму лактуючих голштинів за інтенсивної технології експлуатації

\begin{tabular}{|c|c|c|c|c|}
\hline \multirow{3}{*}{ Група тварин за віком у лактаціях } & \multicolumn{4}{|c|}{ Секреція молочної продукції, кг } \\
\hline & \multirow{2}{*}{ 4\%-ового молока на 1 днів } & \multirow{2}{*}{ те ж на 1 кг живої маси } & \multicolumn{2}{|c|}{ На 1 кг живої маси, кг: } \\
\hline & & & молочного жиру & молочного білка \\
\hline \multicolumn{5}{|c|}{ За повну лактацію } \\
\hline $\mathrm{I}, \mathrm{n}=3772$ & $24,60 \pm 0,06$ & $18,10 \pm 0,09$ & $0,7 \pm 0,003$ & $0,6 \pm 0,002$ \\
\hline II, $n=1928$ & $25,9 \pm 0,1$ & $18,0 \pm 0,1$ & $0,7 \pm 0,004$ & $0,6 \pm 0,003$ \\
\hline III (контрольна), n=1318 & $27,4 \pm 0,14$ & $16,3 \pm 0,12$ & $0,6 \pm 0,05$ & $0,5 \pm 0,004$ \\
\hline$I V, n=449$ & $26,7 \pm 0,26$ & $18,8 \pm 0,20$ & $0,7 \pm 0,01$ & $0,6 \pm 0,01$ \\
\hline$V, n=239$ & $27,4 \pm 0,3$ & $19,1 \pm 0,33$ & $0,7 \pm 0,01$ & $0,6 \pm 0,01$ \\
\hline \multicolumn{5}{|c|}{ За 305 діб лактації } \\
\hline $\mathrm{I}, \mathrm{n}=3772$ & $26,7 \pm 0,05$ & $13,7 \pm 0,03$ & $0,5 \pm 0,03$ & $0,4 \pm 0,001$ \\
\hline II, $n=1928$ & $29,4 \pm 0,1$ & $14,1 \pm 0,05$ & $0,6 \pm 0,002$ & $0,5 \pm 0,002$ \\
\hline III (контрольна), n=1318 & $29,8 \pm 0,12$ & $13,6 \pm 0,06$ & $0,5 \pm 0,003$ & $0,4 \pm 0,002$ \\
\hline $\mathrm{IV}, \mathrm{n}=449$ & $30,8 \pm 0,21$ & $15,0 \pm 0,12$ & $0,6 \pm 0,005$ & $0,5 \pm 0,003$ \\
\hline$V, n=239$ & $30,1 \pm 0,29$ & $16,0 \pm 0,16$ & $0,6 \pm 0,01$ & $0,5 \pm 0,01$ \\
\hline
\end{tabular}

За повний лактаційний період у голштинських різновікових корів секреція молочного жиру на один кілограм живої маси трималась на досить високому рівні та коливалась в межах 0,6-0,7 кг. Так, корови I, II, IV i V мали однакове значення даного показника, який становив у середньому 0,7 кг, що перевищувало тварин III (контрольної) групи у третю лактацію на 14,3 \%, у яких секреція молочного жиру складала 0,6 кг на кілограм живої маси.

Кількість молочного білка, що секретується в розрахунку на 1 кг живої маси у корів III (контрольної) групи у третю лактацію за даний період відрізнялася найменшим значенням - лише 0,5 кг, поступаючись на 20 \% коровам I, II, IV i V груп відповідно у першу, другу, четверту і п'яту лактації, у яких даний показник становив у середньому 0,6 кг.

Характеризуючи секрецію молочного жиру та білка різновікових корів дослідних груп упродовж 305 діб лактаційного періоду необхідно відмітити, що вона була схожа до попереднього аналізу, але мала нижчі показники. Так, близькі та найменші значення даних показників мали тварини I і III (контрольної) груп відповідно у першу та третю лактації відповідно 0,5 кг молочного жиру та 0,4 кг молочного білка на одиницю живої маси. Ці значення поступалися показникам коровам II, IV i V груп відповідно у другу, четверту та п'яту, які, в свою чергу, секретували 0,6 кг молочного жиру та 0,5 кг молочного білка на кілограм живої маси.

Висновки: 1. Реалізація генетичного потенціалу голштинськими коровами не $є$ стабільно запрограмованою, оскільки залежить від індивідуальної реакції на умови експлуатації.

2. На фрізіологічне виснаження організму за інтенсивної технології експлуатації вказує те, що рівень молочної продуктивності у корів від першого до четвертого отелення зростає, після чого дещо знижується.

\section{Список використаної літератури:}

1. Барабанщиков Н.В. Молочное дело. М.: Агропромиздат, 1990. С. 351

2. Твердохлеб Г.В. Химия и физика молока и молочных продуктов. М.: Дели принт, 2006. С. 360

3. Cunnigham E.P. Grossbreedingstrutegies in cattle populations. Proceedings of the Working Simposium of Breed Evaluation and Grossing Experiments with Farm Animals Research institute for Animals Husbandry Schooneord, Zeist. 2004. P. 107 - 127.

4. Саморуков, Ю. О породах в молочном скотоводстве. Молочное и мясное скотоводство. 2013. № 1. С. 21 - 23.

5. Донник, И. М. Влияние инбридинга на молочную продуктивность, качество молока и воспроизводительную способность коров. Аграрный вестник Урала. 2013. № 5 (111). С. 15-19.

6.Кэмпбелл, Дж.Р, Марал, Р.Т. Производство молока / пер. с англ. М.Н. Барабанщикова и др. М.: Колос, 1980. С. 670

7. Кірович, Н. О., Севастьянов, О. Г. Тривалість ембріонального періоду розвитку та молочна продуктивність корів. Аграрний вісник Причорномор'я. Одеса, 2011. Вип.58. С. 40 - 45.

8. Косилов, В. И. Воспроизводительная функция чистопородных и помесных маток. Известия Оренбургского государственного аграрного университета. 2012. № 5 (37). С. 83 - 85.

9. Sorensen, L. H. Genetic parameters for fertility measurements in Holstein heifers: The activity tag Heatime makes a difference. Acta agr. scand. Sect. A. 2013. № 4. P. 169 - 174.

\section{References:}

1.Barabanshhikov, N.V., 1990. Molochnoe delo [Dairy business]. M.: Agropromizdat.

2.Tverdohleb, G.V., 2006. Himija i fizika moloka i molochnyh produktov [Chemistry and Physics of Milk and Dairy Products]. M.: Deli print.

3.Cunnigham, E.P., 2004. Grossbreedingstrutegies in cattle populations. Zeist. Proceedings of the Working Simposium of Breed Evaluation and Grossing Experiments with Farm Animals Research institute for Animals Husbandry Schooneord, pp. 107 127.

4.Samorukov, J.O., 2013. O porodah v molochnom skotovodstve [About breeds in dairy cattle breeding]. Molochnoe $i$ mjasnoe skotovodstvo, no. 1, pp. $21-23$.

5.Donnik, I. M., 2013. Vlijanie inbridinga na molochnuju produktivnost', kachestvo moloka i vosproizvoditel'nuju sposobnost' korov [The effect of inbreeding on milk production, milk quality and cow reproduction]. Agrarnyj vestnik Urala, no. 5 (111), pp. 15 - 
19.

6.Campbell J.R., Maral R.T., 1980. Proizvodstvo moloka [Milk production]. Translaed from English by M.N. Barabanshhikov and others. M.: Kolos.

7.Kirovych, N. O., Sevastianov, O. H., 2011. Tryvalist embrionalnoho periodu rozvytku ta molochna produktyvnist koriv [Duration of embryonic development period and dairy productivity of cows]. Ahrarnyi visnyk Prychornomoria, issue 58, pp. 40 - 45.

8.Kosilov, V. I., 2012. Vosproizvoditel'naja funkcija chistoporodnyh i pomesnyh matok[Reproductive function of purebred and crossbred queens]. Izvestija Orenburgskogo gosudarstvennogo agrarnogo universiteta. no. 5 (37), pp. 83-85.

9.Sorensen, L. H., 2013. Genetic parameters for fertility measurements in Holstein heifers: The activity tag Heatime makes a difference. Acta agr. scand. Sect. A. no. 4, pp 169-174.

\section{Huculak, $A$.}

Dependence of milk productivity Holstein cows on the duration of lactation period and organism's physiological activity

Characterizing the productive qualities of Holstein cows, it is necessary to note a clear increase in milk yield of cows from the first to the fourth lactation, and already at the fifth lactation there is a slight decrease in milk productivity. Thus, cows of the third lactation were no longer characterized by milk yields of up to $9,000 \mathrm{~kg}$ of milk. At the same time, animals of the fourth and fifth lactations also had no milk productivity of up to $9,000 \mathrm{~kg}$, but no more than $10,000 \mathrm{~kg}$ in 305 days of lactation were the same. In the conducted studies, the duration of the lactation period in different cows significantly deviated from the normative indicator, which is 305 days, ie 10 months. Thus, even with the stimulation of ovulation on the ovaries of cows, the duration of lactation exceeds the normative parameters. Particularly long lactation period in maladapted first-borns, which exceeds the norm by $42.9 \%$. However, with the age of the cows, the lactation period, although exceeding the norm, is still noticeable a slight reduction. It is established that the increase in milk productivity of cows occurs from the first to the fourth lactation, and already at the fifth lactation there is a slight decrease in it, indicating some physiological exhaustion of the body. Indicators of the ratio of the magnitude of the milk to their live weight also testify to this. Thus, Holstein animals of the fourth and fifth lactations show the highest rates of both milk productivity for 305 days and physiological activity of the organism. During this period, per kilogram of live weight of cows accounted for 15.0 and $16.0 \mathrm{~kg}$ of secreted milk, respectively, whereas in animals of the first and second lactations this figure was lower by 14.3 and $11.8 \%$, respectively. Animals I and III (control) groups, respectively, in the first and third lactations, respectively, of $0.5 \mathrm{~kg}$ of milk fat and 0.4 $\mathrm{kg}$ of milk protein per unit body weight had the closest and lowest values of milk fat and protein indices. These values were inferior to those of group II, IV and V cows, respectively, in the second, fourth and fifth, which in turn secreted $0.6 \mathrm{~kg}$ of milk fat and $0.5 \mathrm{~kg}$ of milk protein per kilogram of live weight. The realization of genetic potential by Holstein cows is not stably programmed because it depends on the individual response to the operating conditions. The physiological depletion of the body through intensive technology indicates that the level of dairy productivity in cows from the first to the fourth calving increases, and then decreases slightly.

Key words: udium, cow, lactation, milk, physiological activity of the body

Дата надходження до редакції: 14.03.2019 p. 